\title{
Cell Adhesion Molecules and Protein Synthesis Regulation in Neurons
}

\author{
Irina Kozlova, Saroj Sah, Ryan Keable, Iryna Leshchyns'ka, Michael Janitz \\ and Vladimir Sytnyk* \\ School of Biotechnology and Biomolecular Sciences, The University of New South Wales, Sydney, NSW, Australia
}

Cell adhesion molecules (CAMs) mediate interactions of neurons with the extracellular environment by forming adhesive bonds with CAMs on adjacent membranes or via binding to proteins of the extracellular matrix. Binding of CAMs to their extracellular ligands results in the activation of intracellular signaling cascades, leading to changes in neuronal structure and the molecular composition and function of neuronal contacts. Ultimately, many of these changes depend on the synthesis of new proteins. In this review, we summarize the evidence showing that CAMs regulate protein synthesis by modulating the activity of transcription factors, gene expression, protein translation, and the structure and distribution of organelles involved in protein synthesis and transport.

\section{OPEN ACCESS}

Edited by:

Masahito Yamagata, Harvard University, United States

Reviewed by: Davide Comoletti, Victoria University of Wellington, New Zealand Cheng Wang, National Center for Toxicological Research (FDA), United States

${ }^{*}$ Correspondence: Vladimir Sytnyk v.sytnyk@unsw.edu.au

Received: 06 August 2020 Accepted: 16 October 2020 Published: 12 November 2020

Citation:

Kozlova I, Sah S, Keable R, Leshchyns'ka I, Janitz M and Sytnyk V (2020) Cell Adhesion Molecules and Protein Synthesis Regulation in Neurons. Front. Mol. Neurosci. 13:592126. doi: 10.3389/fnmol.2020.592126
Keywords: cell adhesion molecules, neurons, transcription factors, gene expression, translation, endoplasmic reticulum, golgi apparatus

\section{INTRODUCTION}

Protein synthesis in eukaryotes begins with the RNA polymerase II-mediated transcription of protein-coding genes in the nucleus of the cell. The RNA transcripts then undergo post-transcriptional modifications, that include splicing, capping, and polyadenylation (BenYishay and Shav-Tal, 2019). The mature messenger RNA (mRNA) molecules are then exported from the nucleus to the cytosol via the nuclear pore complex (Xie and Ren, 2019). In the cytoplasm, mRNA is either degraded or stabilized, localized and used as a template for protein translation on ribosomes (Martin and Ephrussi, 2009; Keene, 2010). The endoplasmic reticulum (ER) is the main site of translation of cytosolic and membrane proteins by ribosomes located on its surface, although some of the cytosolic proteins are also translated on cytosolic ribosomes (Reid and Nicchitta, 2015).

The highly polarized morphology and function of neurons demand the modification of proteomes locally in axons and dendrites (Glock et al., 2017; Rangaraju et al., 2017). Ribosomes and ER accumulate in somata of neurons but are also distributed along dendrites and axons and are present at synapses. This spatial distribution enables protein synthesis not only in somata but also in dendrites and axons (Steward and Levy, 1982; Holt and Schuman, 2013). The local protein translation in dendrites is particularly active near synapses (Aakalu et al., 2001). It is initiated in response to stimuli inducing synaptogenesis and is required for synaptic plasticity. An extensive overview of the literature on the local protein synthesis in neurons can be found in several recent reviews (Rangaraju et al., 2017; Holt et al., 2019; Pushpalatha and Besse, 2019).

Integral membrane proteins made in the ER concentrate at specialized ER exit sites (ERESs), which are present in the ER throughout the somatodendritic compartment. Proteins are then delivered to the Golgi apparatus (Horton and Ehlers, 2003). 
The neuronal Golgi apparatus primarily localizes in the neuronal somata although Golgi cisternae also extend into dendrites. Discrete dendritic Golgi structures termed Golgi outposts are found in distal dendrites particularly at branch points but are excluded from axons (Horton et al., 2005; Ye et al., 2007). In the soma, proteins synthesized in the ER are delivered to the Golgi apparatus, sorted, and delivered to other neuronal compartments in the Golgi-derived vesicles. In contrast, proteins synthesized locally in the dendritic ER can be sorted via Golgi outposts (reviewed in Ramirez and Couve, 2011; Ehlers, 2013; Valenzuela and Perez, 2015). The Golgi-independent trafficking of locally synthesized proteins via recycling endosomes in dendrites has also been described (Bowen et al., 2017).

Neuronal growth, synapse formation, and function are regulated by cell adhesion molecules (CAMs). These cell surface glycoproteins have large extracellular domains, which mediate the interactions between neurons and the extracellular environment by forming adhesive bonds with proteins located on neighboring cells or in the extracellular matrix. Neurons express multiple families of CAMs (Shapiro et al., 2007). Members of the immunoglobulin superfamily (IgSF) and cadherins are characterized by the presence of the immunoglobulin-like and cadherin domains, respectively, and can form either homophilic adhesive bonds by binding to CAMs of the same type or heterophilic adhesive bonds by interacting with CAMs of a different type. Heterophilic adhesive bonds are also formed by other CAMs, such as post-synaptic neuroligins and presynaptic neurexins, or integrins, which bind to proteins of the extracellular matrix. CAMs are the carriers and receptors for glycans, which modulate the formation of adhesive bonds and interactions of CAMs with other extracellular proteins (Sytnyk et al., 2020). By forming adhesive bonds, CAMs mechanically stabilize synapses. They also assemble the transsynaptic scaffold recruiting other scaffolding proteins, neurotransmitter receptors, and different components of the synaptic machinery. Thereby, CAMs modulate the formation, maturation, stability, and strength of synapses (reviewed in Martin and Kandel, 1996; Togashi et al., 2009; Sytnyk et al., 2017; Tan et al., 2017; Keable et al., 2020). Also, CAMs initiate multiple intracellular signaling cascades in response to binding to their extracellular ligands (Juliano, 2002; Maness and Schachner, 2007; Leshchyns'ka and Sytnyk, 2016a). In the following sections, we summarize the current evidence indicating that the CAM-mediated signaling modulates the protein synthesis machinery, which produces proteins required for CAM-dependent changes in neuronal growth and function.

\section{CAMS REGULATE TRANSCRIPTION}

The idea that CAMs regulate gene expression was suggested by studies showing that the formation of cell-to-cell or cellto-extracellular matrix contacts results in changes in gene expression. Dissociation of retina tissues results in a rapid decline in cortisol-induced mRNA expression of glutamine synthetase. This effect is reversed when cells are allowed to re-establish contacts with other cells (Vardimon et al., 1988). Disruption of cell-to-cell contacts in the Xenopus laevis embryo causes a decrease in $\alpha$-actin mRNA levels (Sargent et al., 1986). When cultured on plastic, primary mouse mammary epithelial cells do not synthesize milk proteins but regain this ability when cultured on the Engelbreth-Holm-Swarm tumor matrix, laminin or heparan sulfate proteoglycans (Li et al., 1987).

Aggregation of chicken embryo brain cells causes changes in the transcription of several genes, including genes coding for the IgSF CAMs the neural cell adhesion molecule (NCAM), and neuron-glia cell adhesion molecule (Ng-CAM). This effect is inhibited by preventing cell aggregation with anti-NCAM Fab' fragments (Mauro et al., 1994), indicating that changes in gene expression are induced by this CAM. Other CAMs also regulate transcription. The loss of L1, an IgSF CAM, in the brains of L1-deficient mice causes a reduction in the mRNA levels of microtubule-associated protein 2 (MAP2; Poplawski et al., 2012). Microarray analysis in the hippocampus of mice with ablated expression of neuronal growth regulator 1 (NEGR1), another IgSF CAM, identified 21 upregulated and 54 downregulated genes (Noh et al., 2019). Transcriptome sequencing identified 310 and 119 genes differentially expressed in the hippocampus of 22- and 66-day-old mice deficient in cadherin 13, respectively, indicating that the CAM-dependent regulation of transcription is developmentally regulated (Kiser et al., 2019).

Transcriptional changes observed in the brains of transgenic mice can also reflect the overall anatomical and functional changes in the brain. For example, the information processing mediated by immediate-early gene expression is altered in NCAM-deficient mice. In these animals, novel taste causes increased mRNA expression of a DNA-binding regulator protein c-fos in the amygdala, neutral taste causes increased mRNA expression of the activity-regulated cytoskeleton-associated protein (Arc) in the dentate gyrus, whereas the novelty-induced Arc increase in the cingulate cortex is inhibited (Montag-Sallaz et al., 2003). However, direct activation of CAMs via induction of homophilic adhesion or by using artificial ligands also results in changes in gene expression. In cultured astrocytes, the application of soluble NCAM purified from the early postnatal rat brain, which homophilically binds to the cell surface NCAM, induces changes in expression of 75 genes including an increase in mRNA levels of glutamine synthetase and calreticulin (Crossin et al., 1997). In rat hippocampal precursor cells, soluble NCAM induces an increase in the transcript levels of NR1 and GluR1, subunits of NMDA and AMPA receptors, respectively (Shin et al., 2002). Antibodies against the extracellular domain of NCAM used as an artificial ligand trigger the expression of Nr2f6, Lrp2, and Snca in cultured cerebellar neurons (Westphal et al., 2017b). Altogether, these studies indicate that CAMs are directly involved in the regulation of transcription.

\section{CAMS REGULATE TRANSCRIPTION FACTORS}

In cultured astrocytes, activation of NCAM with soluble NCAM induces an increase in the activity of promoters containing glucocorticoid response elements (Crossin et al., 1997). In cultured rat cerebellar neurons and rat forebrain astrocytes, purified NCAM, the IgIII domain of NCAM or antibodies 
against NCAM induce increased binding of the NF-kB family of transcription factors to DNA and increased transcription of the NF-kB responsive genes, such as $I k B-\alpha$ (Krushel et al., 1999; Table 1). In rat hippocampal precursor cells, soluble NCAM activates expression of transcription factors Neurogenin 1 (Ngn1) and NeuroD but decreases expression of Hes5 (Shin et al., 2002). The formation of neurites induced by homophilic interactions of NCAM in PC12-E2 cells is inhibited by overexpression of HES-1, a transcription repressor (Jessen et al., 2003). Altogether, these data indicate that NCAM regulates transcription by changing the expression and activities of transcription factors and transcription repressors in a cell type-specific manner. Other CAMs also regulate transcription factors (Table 1). Levels of inducible transcription factors, including neuronal PAS domain protein 4 (NPAS4), are reduced in embryonic cortical neurons derived from mice with ablated expression of a CAM amyloid precursor protein (Opsomer et al., 2020). In mouse cortical organoids deficient in contactinassociated protein-like 2 (Cntnap2), a member of the neurexin CAM family, levels of Dlx2, Nkx2.1, Ascl1, NeuroD, and Neurog2 transcription factors are reduced (Hali et al., 2020). In Drosophila, knock-down of the CAM klingon (Klg) causes a decrease in levels of a glial-specific paired-like homeodomain transcription factor Repo (Matsuno et al., 2015).

Activation of NCAM with soluble NCAM in neurons or NCAM overexpression in heterologous cells induces activation of the mitogen-activated protein kinase (MAPK) pathway
(Niethammer et al., 2002; Shin et al., 2002; Figure 1), which triggers phosphorylation and changes activity of multiple substrates in the nucleus (Morrison, 2012). For example, NCAM triggers serine 133 phosphorylation and activation of the transcription factor cyclic AMP response-element binding protein (CREB; Aonurm-Helm et al., 2008; Ditlevsen et al., 2008), which depend in part on the intact MAPK pathway (Schmid et al., 1999). NCAM triggers the MAPK pathway by binding to the fibroblast growth factor receptor (FGFR) and by activating lipid raft-associated kinases, such as Fyn (Niethammer et al., 2002; Bodrikov et al., 2005, 2008). MAPK inhibitors block the NCAM-dependent neurite outgrowth in cultured rat dopaminergic, hippocampal and cerebellar granule neurons, as well as in PC12-E2 cells (Kolkova et al., 2000; Neiiendam et al., 2004). Other IgSF CAMs also trigger the MAPK pathway. MAPK inhibitors inhibit neurite outgrowth induced by soluble fragments of NEGR1 in embryonic mouse cortical neurons (Pischedda and Piccoli, 2015), and block an increase in the expression of MAP2 induced by antibodies against L1 in mouse hippocampal neurons (Poplawski et al., 2012). The MAPK pathway is also triggered by other CAM families, such as cadherins (Yasuda et al., 2007; Lelievre et al., 2012) and integrins (Dalton et al., 2020). Interestingly, the loss of Ncadherin-mediated adhesion also results in the activation of the MAPK pathway in cultured cortical neurons (Ando et al., 2011).

Recent studies indicate that gene expression can also be regulated by the proteolytic fragments of cell surface receptors,

\begin{tabular}{|c|c|c|c|c|c|}
\hline CAM & $\begin{array}{l}\text { Transcriptional } \\
\text { regulator/Mode of } \\
\text { regulation }\end{array}$ & Cell type & $\begin{array}{l}\text { Examples of the } \\
\text { regulated gene(s) }\end{array}$ & Functional outcome & Reference(s) \\
\hline APP & Not known & $\begin{array}{l}\text { Mouse embryonic cortical } \\
\text { neurons }\end{array}$ & $\begin{array}{l}\text { Promotes the expression of } \\
\text { NPAS4, } \\
\text { downregulates } \\
\text { GAD65, increases } \\
\text { GABAR } \alpha 1\end{array}$ & $\begin{array}{l}\text { A decrease in the production of } \\
\text { inhibitory neurotransmitter } \\
\text { GABA }\end{array}$ & Opsomer et al. (2020) \\
\hline \multirow[t]{2}{*}{ Cntnap2 } & Not known & Mouse cortical organoids & $\begin{array}{l}\text { Promotes the expression of } \\
\text { Dlx2, Nkx2.1, Ascl1 }\end{array}$ & GABAergic neurons production & Hali et al. (2020) \\
\hline & & Mouse cortical organoids & $\begin{array}{l}\text { Promotes the expression of } \\
\text { NeuroD, Neurog2 }\end{array}$ & $\begin{array}{l}\text { Neuronal differentiation and } \\
\text { migration }\end{array}$ & \\
\hline Klg & Not known & Drosophila glial cells & $\begin{array}{l}\text { Promotes the expression of } \\
\text { repo }\end{array}$ & Long-term memory formation & Matsuno et al. (2015) \\
\hline L1 & Activates MAPK & $\begin{array}{l}\text { Mouse hippocampal } \\
\text { neurons }\end{array}$ & Increases MAP2 & Neurite outgrowth & Poplawski et al. (2012) \\
\hline \multirow[t]{3}{*}{ NCAM } & $\begin{array}{l}\text { Increases binding of } \\
\text { NF-kB to DNA }\end{array}$ & $\begin{array}{l}\text { Rat cerebella neurons and } \\
\text { in neonatal forebrain } \\
\text { astrocytes }\end{array}$ & Increases IkB-a & Not known & Krushel et al. (1999) \\
\hline & Not known & $\begin{array}{l}\text { Rat hippocampal precursor } \\
\text { cells }\end{array}$ & $\begin{array}{l}\text { Promotes the expression of } \\
\text { Ngn1, NeuroD, NR1, and } \\
\text { GluR1, inhibits expression } \\
\text { of Hes5 }\end{array}$ & $\begin{array}{l}\text { Differentiation to glutamatergic } \\
\text { neuronal cell type }\end{array}$ & Shin et al. (2002) \\
\hline & $\begin{array}{l}\text { Activates MAPK } \\
\text { pathway, } \\
\text { phosphorylates CREB }\end{array}$ & $\begin{array}{l}\text { Rat hippocampal precursor } \\
\text { cells, cultured } \\
\text { dopaminergic, } \\
\text { hippocampal, cerebral } \\
\text { granule neurons, in } \\
\text { PC12-E2 and rat } \\
\text { neuroblastoma cell lines }\end{array}$ & Not known & Neurite outgrowth & $\begin{array}{l}\text { Schmid et al. (1999); } \\
\text { Kolkova et al. (2000); Shin } \\
\text { et al. (2002); Neiiendam } \\
\text { et al. (2004); Aonurm-Helm } \\
\text { et al. (2008); Ditlevsen et al. } \\
\text { (2008) }\end{array}$ \\
\hline Negr1 & $\begin{array}{l}\text { Activates MAPK } \\
\text { pathway }\end{array}$ & $\begin{array}{l}\text { Mouse embryonic cortical } \\
\text { neurons }\end{array}$ & Not known & Neurite outgrowth & $\begin{array}{l}\text { Pischedda and Piccoli } \\
\text { (2015) }\end{array}$ \\
\hline
\end{tabular}




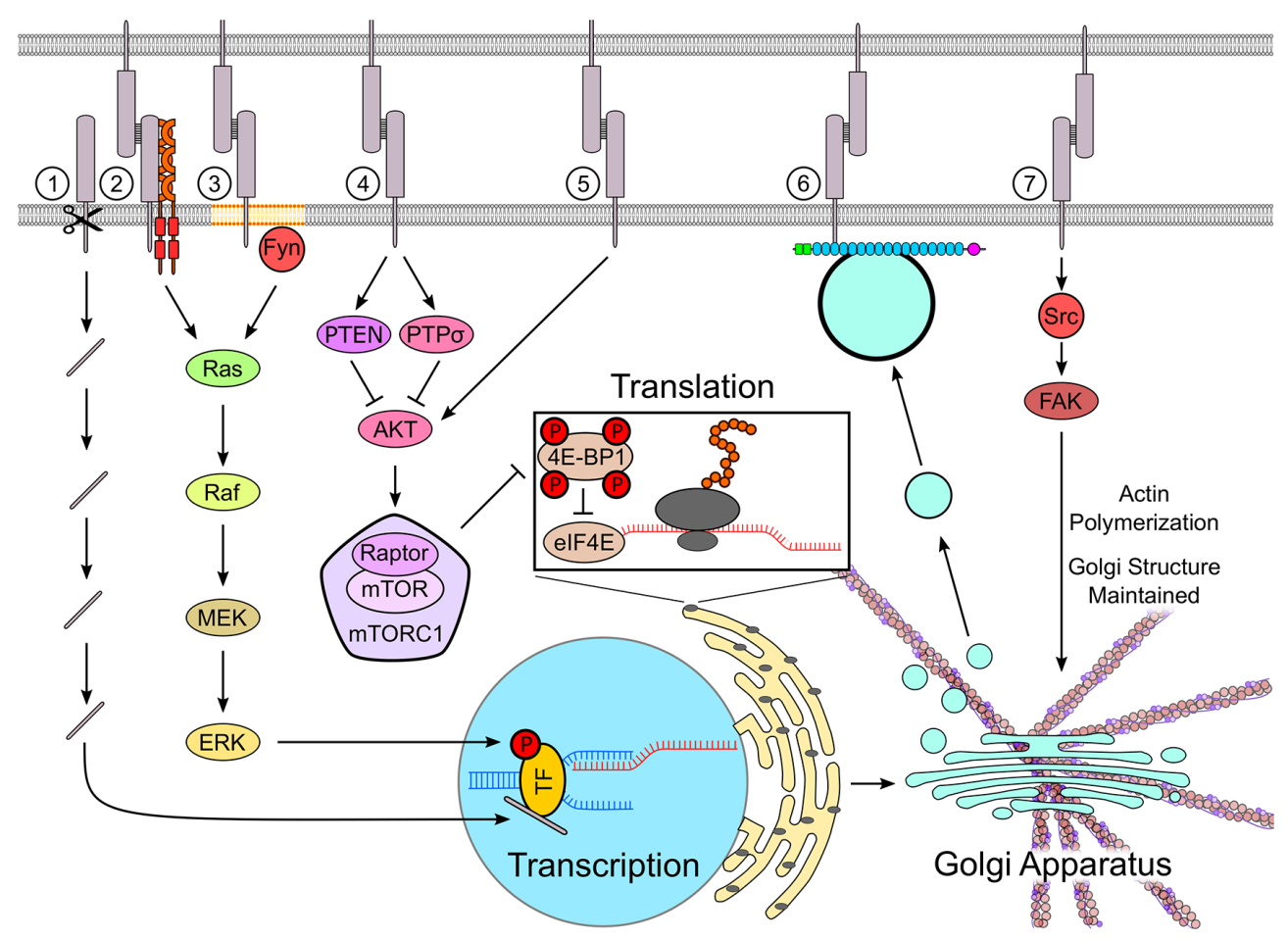

FIGURE 1 | Cell adhesion molecules (CAMs) regulate protein synthesis machinery. CAMs such as neural cell adhesion molecule (NCAM), down syndrome cell adhesion molecule (DSCAM), DSCAM-Like-1 (DSCAML1), and L1 are cleaved by proteases, releasing fragments containing their intracellular domains, which are transported into the nucleus (1). In the nucleus, the CAM-derived fragments regulate the transcription of genes involved in neuronal differentiation and synapse formation by binding to transcription factors. Several CAMs, including NCAM, L1, and N-cadherin, activate the MAPK pathway, which results in the phosphorylation of transcription factors such as cyclic AMP response-element binding protein (CREB), thereby regulating transcription (2). NCAM activates the mitogen-activated protein kinase (MAPK) pathway by clustering and activating fibroblast growth factor receptor (FGFR) at the cell surface (2) and by activating an Src family kinase Fyn in lipid rafts (3). The mammalian target of rapamycin (mTOR) pathway, which controls the rate of translation, can be either activated or inhibited by CAMs. Homophilic binding of NB3 inhibits the mTOR pathway via PTP $\sigma$, whereas neuroligin-3 inhibits the mTOR pathway in cultured neurons and decreases the rate of protein translation by stabilizing the mTOR repressor PTEN (4). Adhesion molecule on glia (AMOG) increases cell size, when expressed in human glioma cells, and activates mTOR in these cells by promoting Akt phosphorylation independently of PI3K (5). The trafficking of newly synthesized proteins via TGN-derived organelles is regulated by NCAM, which binds to these organelles via spectrin, and traps them at contact sites between neurons, thus directing newly synthesized proteins to nascent synapses (6). The activation of Src kinase by CD44 stabilizes the structure of the Golgi apparatus by regulating the polymerization of the actin cytoskeleton (7). See the text for further details and references.

which translocate into the nucleus and regulate transcription. For example, the extracellular matrix protein Reelin induces the cleavage of the Reelin receptor ApoER2 by $\gamma$-secretase. The intracellular domain of this molecule then translocates to the nucleus, where it regulates transcription by regulating the recruitment of transcription factors to the promoters (Telese et al., 2015). Similarly, intracellular fragments of CAMs have been shown to regulate gene expression (Figure 1). NCAM stimulation results in proteolytic processing of NCAM and formation of a C-terminal fragment of NCAM, consisting of the intracellular domain, transmembrane domain, and stub of the extracellular domain. The NCAM fragments are imported into the nucleus (Kleene et al., 2010; Westphal et al., 2017a), where they regulate gene expression (Westphal et al., 2016, 2017b). Stimulation of L1 with antibodies triggers its cleavage by the protease cathepsin resulting in the generation of a transmembrane fragment, which is then sumoylated and imported to the nucleus (Lutz et al., 2012, 2014). Nuclear levels of neuroglian (Nrg), a Drosophila homolog of L1, correlate with the transcript levels of the Myc transcription factor (Kakad et al., 2018). The cleavage of the Down syndrome cell adhesion molecule (DSCAM) and its paralog DSCAMLike-1 (DSCAML1) by $\gamma$-secretase results in the release of their intracellular domains. These domains interact with the importin beta IPO5 via a conserved nuclear localization signal. The domains are transported to the nucleus where they regulate genes involved in neurite outgrowth and synapse formation (Sachse et al., 2019).

\section{CAMs AND REGULATION OF NEURONAL PROTEIN TRANSLATION}

In human endothelial cells, binding of integrins to extracellular matrix-coated beads induces the recruitment of mRNAs and ribosomes to the sites of contacts with the beads (Chicurel et al., 1998) suggesting that CAMs regulate the protein translation machinery. This idea is supported by studies showing that changes in levels of CAMs are accompanied by changes in other 
proteins. Specifically, levels of the membrane-cytoskeleton linker protein spectrin are reduced in the brains of NCAM deficient mice and increased in cultured hippocampal neurons and heterologous cells overexpressing NCAM (Leshchyns'ka et al., 2003). In cultured embryonic chick sympathetic ganglion cells, inhibition of the NCAM mediated adhesion via application of anti-NCAM Fab fragments results in decreased activity of choline acetyltransferase, an enzyme responsible for acetylcholine production (Acheson and Rutishauser, 1988). Levels of the cytoskeletal proteins tubulin and MAP2 are reduced in cultured mouse hippocampal neurons with reduced levels of the neural cell adhesion molecule 2 (NCAM2; Parcerisas et al., 2020). The CAM-dependent changes in protein levels may correlate with changes in transcription. For example, a reduction in MAP2 mRNA levels correlates with reduced MAP2 protein levels in the brains of L1 deficient mice. However, protein levels of both total and phosphorylated ErB2, a tyrosine kinase receptor involved in cell proliferation and migration, are increased, whereas the ErB2 mRNA levels are not altered in the NCAM2 knock-out spinal cord stem cells (Deleyrolle et al., 2015). This data suggests that CAMs also regulate protein levels post-transcriptionally.

The CAM-dependent regulation of translation remains poorly understood. In oligodendrocytes, $\alpha 6 \beta 1$-integrins at oligodendrocyte-axon contacts promote translation of the myelin basic protein (MBP) mRNA by releasing the mRNA from the hnRNP-K-containing transport granules (Laursen et al., 2011). Neuroligin 3 controls protein synthesis by regulating the activity of the mammalian target of rapamycin (mTOR) signaling pathway (Figure 1). Deficiency in neuroligin 3 results in hyperactivation of mTOR signaling, increased phosphorylation of ribosomal protein S6, a target of mTOR pathway, and increased rate of translation in cultured rat hippocampal neurons (Xu et al., 2019). Exposure of human high-grade glioma cells to soluble neuroligin 3 secreted by active neurons results in increased phosphorylation of eukaryotic translation initiation factor 4E-binding protein 1 (4E-BP1), which is an mTOR downstream effector (Venkatesh et al., 2015). Expression of adhesion molecule on glia (AMOG) in AMOG deficient human glioma cells results in phosphorylation of Akt with subsequent activation of mTOR signaling (Scheidenhelm et al., 2005). After spinal cord injury, the mTOR activity in neurons is inhibited by homophilic interactions of an IgSF CAM NB3 in corticospinal axons, which binds to NB3 on glial scar-forming cells (Huang et al., 2016). Together, these studies suggest that CAMs regulate protein translation at several levels including the regulation of release of mRNAs from the transport complexes at sites of translation and regulation of the translation machinery.

\section{CAMs AND REGULATION OF THE ER AND GOLGI APPARATUS}

Limited evidence suggests that CAMs can also regulate local protein synthesis by regulating the recruitment of organelles required for synthesis, sorting, and delivery of proteins to specific locations within neurons. In developing hippocampal neurons, cell surface NCAM interacts with trans-Golgi network-derived organelles via its intracellular domain. NCAM regulates targeting of trans-Golgi network-derived organelles to growth cones and promotes exocytosis and cargo delivery at these sites (Chernyshova et al., 2011). NCAM also captures the transGolgi-derived organelles at sites of neurite-to-neurite contacts, which are then transformed into synapses (Sytnyk et al., 2002; Figure 1). PTP1B is an endoplasmic reticulum (ER) anchored tyrosine phosphatase, which interacts with the tyrosine kinase Src at the surface plasma membrane (Monteleone et al., 2012). PTP1B is targeted to the newly forming cell-matrix adhesions (Hernandez et al., 2006) and may link the ER to CAMs at the cell surface, such as NCAM2, which interacts with Src (Sheng et al., 2015). In human fibroblasts, loss of adhesion results in the disorganization of the Golgi apparatus. Re-establishment of adhesion restores the integrity of the Golgi via the integrin-dependent activation of Arf1, which recruits the microtubule motor protein dynein to control the Golgi organization (Singh et al., 2018). In hippocampal neurons, a CAM CD44 regulates the positioning of the Golgi in the soma via the Src kinase-dependent regulation of the actin cytoskeleton. The knock-down of CD44 causes Golgi fragmentation and dispersion, which is reduced by inhibiting actin polymerization (Skupien et al., 2014; Figure 1).

\section{CONCLUSION}

Neuronal growth during development and synaptic plasticity in the mature brain depends on the synthesis of new proteins. CAMs are well known as regulators of the neuronal morphology, which mediate the interactions between neurons and the extracellular matrix and neighboring cells. In this review, we draw attention to the growing body of work showing that CAMs also regulate transcription and protein translation and that the protein biosynthesis pathways play a key role in the morphological and functional changes induced by CAMs in neurons. Dysregulation of protein synthesis has been observed in different neurodevelopmental and neurodegenerative disorders, including autism spectrum disorders, fragile X syndrome, and Alzheimer's disease (Buffington et al., 2014; Ghosh et al., 2020; Lo and Lai, 2020), which are also associated with abnormalities in the expression or processing of CAMs (Leshchyns'ka et al., 2015; Stewart, 2015; Leshchyns'ka and Sytnyk, 2016b; Chmielewska et al., 2019). Understanding the CAM-mediated regulation of protein synthesis can provide further insight into the etiologies of these conditions and, consequently, lead to new therapies.

\section{AUTHOR CONTRIBUTIONS}

All authors contributed to the literature analysis and writing of the manuscript. All authors contributed to the article and approved the submitted version.

\section{FUNDING}

This work was supported by the National Health and Medical Research Council project grant (APP1129869 to VS). 


\section{REFERENCES}

Aakalu, G., Smith, W. B., Nguyen, N., Jiang, C., and Schuman, E. M. (2001). Dynamic visualization of local protein synthesis in hippocampal neurons. Neuron 30, 489-502. doi: 10.1016/s0896-6273(01)00295-1

Acheson, A., and Rutishauser, U. (1988). Neural cell adhesion molecule regulates cell contact-mediated changes in choline acetyltransferase activity of embryonic chick sympathetic neurons. J. Cell Biol. 106, 479-486. doi: $10.1083 /$ jcb.106.2.479

Ando, K., Uemura, K., Kuzuya, A., Maesako, M., Asada-Utsugi, M., Kubota, M., et al. (2011). N-cadherin regulates p38 MAPK signaling via association with JNK-associated leucine zipper protein: implications for neurodegeneration in Alzheimer disease. J. Biol. Chem. 286, 7619-7628. doi: 10.1074/jbc.M110. 158477

Aonurm-Helm, A., Zharkovsky, T., Jurgenson, M., Kalda, A., and Zharkovsky, A. (2008). Dysregulated CREB signaling pathway in the brain of neural cell adhesion molecule (NCAM)-deficient mice. Brain Res. 124, 104-112. doi: 10.1016/j.brainres.2008.08.091

Ben-Yishay, R., and Shav-Tal, Y. (2019). The dynamic lifecycle of mRNA in the nucleus. Curr. Opin. Cell Biol. 58, 69-75. doi: 10.1016/j.ceb.2019.02.007

Bodrikov, V., Leshchyns'ka, I., Sytnyk, V., Overvoorde, J., den Hertog, J., and Schachner, M. (2005). RPTP $\alpha$ is essential for NCAM-mediated p59fyn activation and neurite elongation. J. Cell Biol. 168, 127-139. doi: 10.1083/jcb. 200405073

Bodrikov, V., Sytnyk, V., Leshchyns'ka, I., den Hertog, J., and Schachner, M. (2008). NCAM induces CaMKIIalpha-mediated RPTP $\alpha$ phosphorylation to enhance its catalytic activity and neurite outgrowth. J. Cell Biol. 182, 1185-1200. doi: $10.1083 /$ jcb. 200803045

Bowen, A. B., Bourke, A. M., Hiester, B. G., Hanus, C., and Kennedy, M. J. (2017). Golgi-independent secretory trafficking through recycling endosomes in neuronal dendrites and spines. eLife 6:e27362. doi: 10.7554/eLife.27362

Buffington, S. A., Huang, W., and Costa-Mattioli, M. (2014). Translational control in synaptic plasticity and cognitive dysfunction. Annu. Rev. Neurosci. 37, 17-38. doi: 10.1146/annurev-neuro-071013-014100

Chernyshova, Y., Leshchyns'ka, I., Hsu, S.-C., Schachner, M., and Sytnyk, V. (2011). The neural cell adhesion molecule promotes FGFR-dependent phosphorylation and membrane targeting of the exocyst complex to induce exocytosis in growth cones. J. Neurosci. 31, 3522-3535. doi: 10.1523/JNEUROSCI.3109-10.2011

Chicurel, M. E., Singer, R. H., Meyer, C. J., and Ingber, D. E. (1998). Integrin binding and mechanical tension induce movement of mRNA and ribosomes to focal adhesions. Nature 392, 730-733. doi: 10.1038/33719

Chmielewska, J. J., Kuzniewska, B., Milek, J., Urbanska, K., and Dziembowska, M. (2019). Neuroligin 1, 2 and 3 regulation at the synapse: FMRP-dependent translation and activity-induced proteolytic cleavage. Mol. Neurobiol. 56, 2741-2759. doi: 10.1007/s12035-018-1243-1

Crossin, K. L., Tai, M. H., Krushel, L. A., Mauro, V. P., and Edelman, G. M. (1997). Glucocorticoid receptor pathways are involved in the inhibition of astrocyte proliferation. Proc. Natl. Acad. Sci. U S A 94, 2687-2692. doi: 10.1073/pnas.94. 6.2687

Dalton, G. D., Carney, S. T., Marshburn, J. D., Norford, D. C., and Howlett, A. C. (2020). CB1 cannabinoid receptors stimulate G $\beta \gamma$-GRK2-mediated FAK phosphorylation at tyrosine 925 to regulate ERK activation involving neuronal focal adhesions. Front. Cell. Neurosci. 14:176. doi: 10.3389/fncel.2020. 00176

Deleyrolle, L., Sabourin, J. C., Rothhut, B., Fujita, H., Guichet, P. O., Teigell, M., et al. (2015). OCAM regulates embryonic spinal cord stem cell proliferation by modulating ErbB2 receptor. PLoS One 10:e0122337. doi: 10.1371/journal.pone. 0122337

Ditlevsen, D. K., Owczarek, S., Berezin, V., and Bock, E. (2008). Relative role of upstream regulators of Akt, ERK and CREB in NCAM- and FGF2-mediated signalling. Neurochem. Int. 53, 137-147. doi: 10.1016/j.neuint.2008.06.011

Ehlers, M. D. (2013). Dendritic trafficking for neuronal growth and plasticity. Biochem. Soc. Trans. 41, 1365-1382. doi: 10.1042/BST20130081

Ghosh, A., Mizuno, K., Tiwari, S. S., Proitsi, P., Gomez Perez-Nievas, B., Glennon, E., et al. (2020). Alzheimer's disease-related dysregulation of mRNA translation causes key pathological features with ageing. Transl. Psychiatry 10:192. doi: 10.1038/s41398-020-00882-7
Glock, C., Heumuller, M., and Schuman, E. M. (2017). mRNA transport and local translation in neurons. Curr. Opin. Neurobiol. 45, 169-177. doi: 10.1016/j.conb. 2017.05.005

Hali, S., Kim, J., Kwak, T. H., Lee, H., Shin, C. Y., and Han, D. W. (2020). Modelling monogenic autism spectrum disorder using mouse cortical organoids. Biochem. Biophys. Res. Commun. 521, 164-171. doi: 10.1016/j.bbrc.2019. 10.097

Hernandez, M. V., Sala, M. G., Balsamo, J., Lilien, J., and Arregui, C. O. (2006) ER-bound PTP1B is targeted to newly forming cell-matrix adhesions. J. Cell Sci. 119, 1233-1243. doi: 10.1242/jcs.02846

Holt, C. E., and Schuman, E. M. (2013). The central dogma decentralized: new perspectives on RNA function and local translation in neurons. Neuron 80 , 648-657. doi: 10.1016/j.neuron.2013.10.036

Holt, C. E., Martin, K. C., and Schuman, E. M. (2019). Local translation in neurons: visualization and function. Nat. Struct. Mol. Biol. 26, 557-566. doi: 10.1038/s41594-019-0263-5

Horton, A. C., and Ehlers, M. D. (2003). Dual modes of endoplasmic reticulumto-Golgi transport in dendrites revealed by live-cell Imaging. J. Neurosci. 23, 6188-6199. doi: 10.1523/JNEUROSCI.23-15-06188.2003

Horton, A. C., Rácz, B., Monson, E. E., Lin, A. L., Weinberg, R. J., and Ehlers, M. D. (2005). Polarized secretory trafficking directs cargo for asymmetric dendrite growth and morphogenesis. Neuron 48, 757-771. doi: 10.1016/j.neuron.2005. 11.005

Huang, Z., Gao, Y., Sun, Y., Zhang, C., Yin, Y., Shimoda, Y., et al. (2016). NB3 signaling mediates the cross-talk between post-traumatic spinal axons and scar-forming cells. EMBO J. 35, 1745-1765. doi: 10.15252/embj.201593460

Jessen, U., Novitskaya, V., Walmod, P. S., Berezin, V., and Bock, E. (2003). Neural cell adhesion molecule-mediated neurite outgrowth is repressed by overexpression of HES-1. J. Neurosci Res. 71, 1-6. doi: 10.1002/jnr.10433

Juliano, R. L. (2002). Signal transduction by cell adhesion receptors and the cytoskeleton: functions of integrins, cadherins, selectins and immunoglobulinsuperfamily members. Annu. Rev. Pharmacol. Toxicol. 42, 283-323. doi: 10.1146/annurev.pharmtox.42.090401.151133

Kakad, P. P., Penserga, T., Davis, B. P., Henry, B., Boerner, J., Riso, A., et al. (2018). An ankyrin-binding motif regulates nuclear levels of L1-type neuroglian and expression of the oncogene Myc in Drosophila neurons. J. Biol. Chem. 293, 17442-17453. doi: 10.1074/jbc.RA118.004240

Keable, R., Leshchyns'ka, I., and Sytnyk, V. (2020). Trafficking and activity of glutamate and GABA receptors: regulation by cell adhesion molecules. Neuroscientist 26, 415-437. doi: 10.1177/1073858420921117

Keene, J. D. (2010). Minireview: global regulation and dynamics of ribonucleic Acid. Endocrinol. 151, 1391-1397. doi: 10.1210/en.2009-1250

Kiser, D. P., Popp, S., Schmitt-Bohrer, A. G., Strekalova, T., van den Hove, D. L., Lesch, K. P., et al (2019). Early-life stress impairs developmental programming in Cadherin 13 (CDH13)-deficient mice. Prog. Neuropsychopharmacol. Biol. Psychiatry 89, 158-168. doi: 10.1016/j.pnpbp.2018.08.010

Kleene, R., Mzoughi, M., Joshi, G., Kalus, I., Bormann, U., Schulze, C., et al (2010). NCAM-induced neurite outgrowth depends on binding of calmodulin to NCAM and on nuclear import of NCAM and fak fragments. J. Neurosci. 30, 10784-10798. doi: 10.1523/JNEUROSCI.0297-10.2010

Kolkova, K., Novitskaya, V., Pedersen, N., Berezin, V., and Bock, E. (2000). Neural cell adhesion molecule-stimulated neurite outgrowth depends on activation of protein kinase $\mathrm{C}$ and the Ras-mitogen-activated protein kinase pathway. J. Neurosci. 20, 2238-2246. doi: 10.1523/JNEUROSCI.20-06-02238.2000

Krushel, L. A., Cunningham, B. A., Edelman, G. M., and Crossin, K. L. (1999). NF$\kappa \mathrm{B}$ activity is induced by neural cell adhesion molecule binding to neurons and astrocytes. J. Biol. Chem. 274, 2432-2439. doi: 10.1074/jbc.274.4.2432

Laursen, L. S., Chan, C. W., and Ffrench-Constant, C. (2011). Translation of myelin basic protein mRNA in oligodendrocytes is regulated by integrin activation and hnRNP-K. J. Cell Biol. 192, 797-811. doi: 10.1083/jcb.2010 07014

Lelievre, E. C., Plestant, C., Boscher, C., Wolff, E., Mege, R. M., and Birbes, H. (2012). N-cadherin mediates neuronal cell survival through Bim downregulation. PLoS One 7:e33206. doi: 10.1371/journal.pone.0033206

Leshchyns'ka, I., Liew, H. T., Shepherd, C., Halliday, G. M., Stevens, C. H., Ke, Y. D., et al. (2015). A $\beta$-dependent reduction of NCAM2-mediated synaptic adhesion contributes to synapse loss in Alzheimer's disease. Nat. Commun. 6:8836. doi: $10.1038 /$ ncomms 9836 
Leshchyns'ka, I., and Sytnyk, V. (2016a). Reciprocal interactions between cell adhesion molecules of the immunoglobulin superfamily and the cytoskeleton in neurons. Front. Cell Dev. Biol. 4:9. doi: 10.3389/fcell.2016.00009

Leshchyns'ka, I., and Sytnyk, V. (2016b). Synaptic cell adhesion molecules in Alzheimer's disease. Neural plast. 2016:6427537. doi: 10.1155/2016/6427537

Leshchyns'ka, I., Sytnyk, V., Morrow, J. S., and Schachner, M. (2003). Neural cell adhesion molecule (NCAM) association with PKC $\beta 2$ via $\beta$ I spectrin is implicated in NCAM-mediated neurite outgrowth. J. Cell Biol. 161, 625-639. doi: $10.1083 /$ jcb. 200303020

Li, M. L., Aggeler, J., Farson, D. A., Hatier, C., Hassell, J., and Bissell, M. J. (1987). Influence of a reconstituted basement membrane and its components on casein gene expression and secretion in mouse mammary epithelial cells. Proc. Natl. Acad. Sci. U S A 84, 136-140. doi: 10.1073/pnas.84.1.136

Lo, L. H., and Lai, K. O. (2020). Dysregulation of protein synthesis and dendritic spine morphogenesis in ASD: studies in human pluripotent stem cells. Mol. Autism. 11:40. doi: 10.1186/s13229-020-00349-y

Lutz, D., Wolters-Eisfeld, G., Joshi, G., Djogo, N., Jakovcevski, I., Schachner, M., et al. (2012). Generation and nuclear translocation of sumoylated transmembrane fragment of cell adhesion molecule L1. J. Biol. Chem. 287, 17161-17175. doi: 10.1074/jbc.M112.346759

Lutz, D., Wolters-Eisfeld, G., Schachner, M., and Kleene, R. (2014). Cathepsin E generates a sumoylated intracellular fragment of the cell adhesion molecule L1 to promote neuronal and Schwann cell migration as well as myelination. J. Neurochem. 128, 713-724. doi: 10.1111/jnc.12473

Maness, P. F., and Schachner, M. (2007). Neural recognition molecules of the immunoglobulin superfamily: signaling transducers of axon guidance and neuronal migration. Nat. Neurosci. 10, 19-26. doi: 10.1038/nn1827

Martin, K. C., and Ephrussi, A. (2009). mRNA localization: gene expression in the spatial dimension. Cell 136, 719-730. doi: 10.1016/j.cell.2009.01.044

Martin, K. C., and Kandel, E. R. (1996). Cell adhesion molecules, CREB and the formation of new synaptic connections. Neuron 17, 567-570. doi: 10.1016/s0896-6273(00)80188-9

Matsuno, M., Horiuchi, J., Yuasa, Y., Ofusa, K., Miyashita, T., Masuda, T., et al. (2015). Long-term memory formation in Drosophila requires training-dependent glial transcription. J. Neurosci. 35, 5557-5565. doi: 10.1523/JNEUROSCI.3865-14.2015

Mauro, V. P., Wood, I. C., Krushel, L., Crossin, K. L., and Edelman, G. M. (1994). Cell adhesion alters gene transcription in chicken embryo brain cells and mouse embryonal carcinoma cells. Proc. Natl. Acad. Sci. U S A 91, 2868-2872. doi: 10.1073/pnas.91.7.2868

Montag-Sallaz, M., Montag, D., and Schachner, M. (2003). Altered processing of novel information in N-CAM-deficient mice. Neuroreport 14, 1343-1346. doi: 10.1097/01.wnr.0000077549.91466.4c

Monteleone, M. C., Gonzalez Wusener, A. E., Burdisso, J. E., Conde, C., Caceres, A., and Arregui, C. O. (2012). ER-bound protein tyrosine phosphatase PTP1B interacts with Src at the plasma membrane/substrate interface. PLoS One 7:e38948. doi: 10.1371/journal.pone.0038948

Morrison, D. K. (2012). MAP kinase pathways. Cold Spring Harb. Perspect. Biol. 4:a011254. doi: 10.1101/cshperspect.a011254

Neiiendam, J. L., Kohler, L. B., Christensen, C., Li, S., Pedersen, M. V., Ditlevsen, D. K., et al. (2004). An NCAM-derived FGF-receptor agonist, the FGL-peptide, induces neurite outgrowth and neuronal survival in primary rat neurons. J. Neurochem. 91, 920-935. doi: 10.1111/j.1471-4159.2004. 02779.x

Niethammer, P., Delling, M., Sytnyk, V., Dityatev, A., Fukami, K., and Schachner, M. (2002). Cosignaling of NCAM via lipid rafts and the FGF receptor is required for neuritogenesis. J. Cell Biol. 157, 521-532. doi: $10.1083 /$ jcb.200109059

Noh, K., Lee, H., Choi, T. Y., Joo, Y., Kim, S. J., Kim, H., et al. (2019). Negrl controls adult hippocampal neurogenesis and affective behaviors. Mol. Psychiatry 24, 1189-1205. doi: 10.1038/s41380-018-0347-3

Opsomer, R., Contino, S., Perrin, F., Gualdani, R., Tasiaux, B., Doyen, P., et al. (2020). Amyloid precursor protein (APP) controls the expression of the transcriptional activator Neuronal PAS Domain Protein 4 (NPAS4) and synaptic GABA release. eNeuro 7:ENEURO.0322-19.2020. doi: 10.1523/ENEURO.0322-19.2020

Parcerisas, A., Pujadas, L., Ortega-Gasco, A., Perello-Amoros, B., Viais, R., Hino, K., et al. (2020). NCAM2 regulates dendritic and axonal differentiation through the cytoskeletal proteins MAP2 and 14-3-3. Cereb. Cortex. 30, 3781-3799. doi: 10.1093/cercor/bhz342

Pischedda, F., and Piccoli, G. (2015). The IgLON family member Negr1 promotes neuronal arborization acting as soluble factor via FGFR2. Front. Mol. Neurosci. 8:89. doi: 10.3389/fnmol.2015.00089

Poplawski, G. H., Tranziska, A. K., Leshchyns'ka, I., Meier, I. D., Streichert, T., Sytnyk, V., et al. (2012). L1CAM increases MAP2 expression via the MAPK pathway to promote neurite outgrowth. Mol. Cell. Neurosci. 50, 169-178. doi: 10.1016/j.men.2012.03.010

Pushpalatha, K. V., and Besse, F. (2019). Local translation in axons: when membraneless RNP granules meet membrane-bound organelles. Front. Mol. Biosci. 6:129. doi: 10.3389/fmolb.2019.00129

Ramirez, O. A., and Couve, A. (2011). The endoplasmic reticulum and protein trafficking in dendrites and axons. Trends Cell Biol. 21, 219-227. doi: 10.1016/j. tcb.2010.12.003

Rangaraju, V., Tom Dieck, S., and Schuman, E. M. (2017). Local translation in neuronal compartments: how local is local? EMBO Rep. 18, 693-711. doi: 10.15252/embr.201744045

Reid, D. W., and Nicchitta, C. V. (2015). Diversity and selectivity in mRNA translation on the endoplasmic reticulum. Nat. Rev. Mol. Cell Biol. 16, 221-231. doi: 10.1038/nrm3958

Sachse, S. M., Lievens, S., Ribeiro, L. F., Dascenco, D., Masschaele, D., Horre, K., et al. (2019). Nuclear import of the DSCAM-cytoplasmic domain drives signaling capable of inhibiting synapse formation. EMBO J. 38:e99669. doi: $10.15252 / \mathrm{embj} .201899669$

Sargent, T. D., Jamrich, M., and Dawid, I. B. (1986). Cell interactions and the control of gene activity during early development of Xenopus laevis. Dev. Biol. 114, 238-246. doi: 10.1016/0012-1606(86)90399-4

Scheidenhelm, D. K., Cresswell, J., Haipek, C. A., Fleming, T. P., Mercer, R. W., and Gutmann, D. H. (2005). Akt-dependent cell size regulation by the adhesion molecule on glia occurs independently of phosphatidylinositol 3-kinase and Rheb signaling. Mol. Cell. Biol. 25, 3151-3162. doi: 10.1128/MCB.25.8.31513162.2005

Schmid, R. S., Graff, R. D., Schaller, M. D., Chen, S., Schachner, M. Hemperly, J. J., et al. (1999). NCAM stimulates the Ras-MAPK pathway and CREB phosphorylation in neuronal cells. J. Neurobiol. 38, 542-558.

Shapiro, L., Love, J., and Colman, D. R. (2007). Adhesion molecules in the nervous system: structural insights into function and diversity. Annu. Rev. Neurosci. 30, 451-474. doi: 10.1146/annurev.neuro.29.051605.113034

Sheng, L., Leshchyns'ka, I., and Sytnyk, V. (2015). Neural cell adhesion molecule 2 promotes the formation of filopodia and neurite branching by inducing submembrane increases in $\mathrm{Ca}^{2+}$ levels. J. Neurosci. 35, 1739-1752. doi: 10.1523/JNEUROSCI.1714-14.2015

Shin, M. H., Lee, E. G., Lee, S. H., Lee, Y. S., and Son, H. (2002). Neural cell adhesion molecule (NCAM) promotes the differentiation of hippocampal precursor cells to a neuronal lineage, especially to a glutamatergic neural cell type. Exp. Mol. Med. 34, 401-410. doi: 10.1038/emm.2002.57

Singh, V., Erady, C., and Balasubramanian, N. (2018). Cell-matrix adhesion controls Golgi organization and function through Arfl activation in anchorage-dependent cells. J. Cell Sci. 131:jcs215855. doi: 10.1242/jcs. 215855

Skupien, A., Konopka, A., Trzaskoma, P., Labus, J., Gorlewicz, A., Swiech, L., et al. (2014). CD44 regulates dendrite morphogenesis through Src tyrosine kinasedependent positioning of the Golgi. J. Cell Sci. 127, 5038-5051. doi: 10.1242/jcs. 154542

Steward, O., and Levy, W. B. (1982). Preferential localization of polyribosomes under the base of dendritic spines in granule cells of the dentate gyrus. J. Neurosci. 2, 284-291. doi: 10.1523/JNEUROSCI.02-03-002 84.1982

Stewart, L. T. (2015). Cell adhesion proteins and the pathogenesis of autism spectrum disorders. J. Neurophysiol. 113, 1283-1286. doi: 10.1152/jn.00 780.2013

Sytnyk, V., Leshchyns'ka, I., Delling, M., Dityateva, G., Dityatev, A., and Schachner, M. (2002). Neural cell adhesion molecule promotes accumulation of TGN organelles at sites of neuron-to-neuron contacts. J. Cell Biol. 159, 649-661. doi: $10.1083 /$ jcb. 200205098

Sytnyk, V., Leshchyns'ka, I., and Schachner, M. (2017). Neural cell adhesion molecules of the immunoglobulin superfamily regulate synapse formation, 
maintenance and function. Trends Neurosci. 40, 295-308. doi: 10.1016/j.tins. 2017.03.003

Sytnyk, V., Leshchyns'ka, I., and Schachner, M. (2020). Neural glycomics: the sweet side of nervous system functions. Cell. Mol. Life Sci. doi: 10.1007/s00018020-03578-9 [Epub ahead of Print].

Tan, R. P. A., Leshchyns'ka, I., and Sytnyk, V. (2017). Glycosylphosphatidylinositol-anchored immunoglobulin superfamily cell adhesion molecules and their role in neuronal development and synapse regulation. Front. Mol. Neurosci. 10:378. doi: 10.3389/fnmol.2017.00378

Telese, F., Ma, Q., Perez, P. M., Notani, D., Oh, S., Li, W., et al. (2015). LRP8-reelin-regulated neuronal enhancer signature underlying learning and memory formation. Neuron 86, 696-710. doi: 10.1016/j.neuron.2015. 03.033

Togashi, H., Sakisaka, T., and Takai, Y. (2009). Cell adhesion molecules in the central nervous system. Cell Adh. Migr. 3, 29-35. doi: 10.4161/cam.3.1.6773

Valenzuela, J. I., and Perez, F. (2015). Diversifying the secretory routes in neurons. Front. Neurosci. 9:358. doi: 10.3389/fnins.2015.0035826500481

Vardimon, L., Fox, L. L., Degenstein, L., and Moscona, A. A. (1988). Cell contacts are required for induction by cortisol of glutamine synthetase gene transcription in the retina. Proc. Natl. Acad. Sci. U S A 85, 5981-5985. doi: 10.1073 /pnas.85.16.5981

Venkatesh, H. S., Johung, T. B., Caretti, V., Noll, A., Tang, Y., Nagaraja, S., et al. (2015). Neuronal activity promotes glioma growth through Neuroligin-3 Secretion. Cell 161, 803-816. doi: 10.1016/j.cell.2015.04.012

Westphal, N., Kleene, R., Lutz, D., Theis, T., and Schachner, M. (2016). Polysialic acid enters the cell nucleus attached to a fragment of the neural cell adhesion molecule NCAM to regulate the circadian rhythm in mouse brain. Mol. Cell. Neurosci. 74, 114-127. doi: 10.1016/j.mcn.2016.05.003

Westphal, N., Loers, G., Lutz, D., Theis, T., Kleene, R., and Schachner, M. (2017a). Generation and intracellular trafficking of a polysialic acid-carrying fragment of the neural cell adhesion molecule NCAM to the cell nucleus. Sci. Rep. 7:8622. doi: 10.1038/s41598-017-09468-8

Westphal, N., Theis, T., Loers, G., Schachner, M., and Kleene, R. (2017b). Nuclear fragments of the neural cell adhesion molecule NCAM with or without polysialic acid differentially regulate gene expression. Sci. Rep. 7:13631. doi: 10.1038/s41598-017-14056-x

Xie, Y., and Ren, Y. (2019). Mechanisms of nuclear mRNA export: a structural perspective. Traffic 20, 829-840. doi: 10.1111/tra.12691

Xu, J., Du, Y. L., Xu, J. W., Hu, X. G., Gu, L. F., Li, X. M., et al. (2019). Neuroligin 3 regulates dendritic outgrowth by modulating Akt/mTOR signaling. Front. Cell Neurosci. 13:518. doi: 10.3389/fncel.2019.00518

Yasuda, S., Tanaka, H., Sugiura, H., Okamura, K., Sakaguchi, T., Tran, U., et al. (2007). Activity-induced protocadherin arcadlin regulates dendritic spine number by triggering $\mathrm{N}$-cadherin endocytosis via TAO2 $\beta$ and p38 MAP kinases. Neuron 56, 456-471. doi: 10.1016/j.neuron.2007.08.020

Ye, B., Zhang, Y., Song, W., Younger, S. H., Jan, L. Y., and Jan, Y. N.. (2007) Growing dendrites and axons differ in their reliance on the secretory pathway. Cell 130, 717-729. doi: 10.1016/j.cell.2007.06.032

Conflict of Interest: The authors declare that the research was conducted in the absence of any commercial or financial relationships that could be construed as a potential conflict of interest.

Copyright (๑) 2020 Kozlova, Sah, Keable, Leshchyns'ka, Janitz and Sytnyk. This is an open-access article distributed under the terms of the Creative Commons Attribution License (CC BY). The use, distribution or reproduction in other forums is permitted, provided the original author(s) and the copyright owner(s) are credited and that the original publication in this journal is cited, in accordance with accepted academic practice. No use, distribution or reproduction is permitted which does not comply with these terms. 